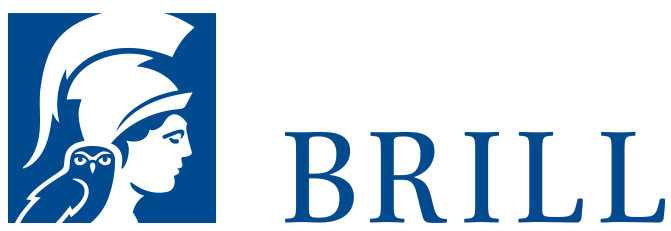

\title{
Networks of Refugees from Nazi Germany
}

\section{Continuities, Reorientations, and Collaborations in Exile}

Volume Editor: Helga Schreckenberger

This volume focuses on coalitions and collaborations formed by refugees from Nazi Germany in their host countries. Exile from Nazi Germany was a global phenomenon involving the expulsion and displacement of entire families, organizations, and communities. While forced emigration inevitable meant loss of familiar structures and surroundings, successful integration into often very foreign cultures was possible due to the exiles' ability to access and/or establish networks. By focusing on such networks rather than on individual experiences, the contributions in this volume provide a complex and nuanced analysis of the multifaceted, interacting factors of the exile experience. This approach connects the NSexile to other forms of displacement and persecution and locates it within the ruptures of civilization dominating the twentieth and twenty-first centuries.

Contributors are: Dieter Adolph, Jacob Boas, Margit Franz, Katherine Holland, Birgit Maier-Katkin Leonie Marx, Wolfgang Mieder, Thomas Schneider, Helga Schreckenberger, Swen Steinberg, Karina von Tippelskirch, Jörg Thunecke, Jacqueline Vansant, and Veronika Zwerger

Readership

All interested in the global impact of exile from Nazi-Germany, political and artistic networks in exile, political activities in exile, network theory, and migration.

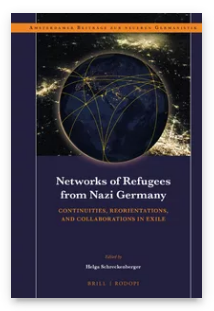

Pages: $\mathrm{x}, 294 \mathrm{pp}$.

Language:

English

Subjects:

Migration

History, History,

German,

Literature and

Cultural Studies,

Jewish History \&

Culture, History,

Sociology \&

Anthropology,

Jewish Studies

Publisher: Brill

Series:

Amsterdamer

Beiträge zur

neueren

Germanistik,

Volume: 87

Amsterdamer

Beiträge zur

neueren

Germanistik,

Volume: 87

E-Book (PDF)

Released online:

o1 Aug 2016

ISBN: 978-90-

O4-32273-8

List price

USD $\$ 152.00$ 
Publication date:

Helga Schreckenberger, Ph.D. (1985), is Professor of German at 19 Aug 2016 the University of Vermont. She has published widely in the areas ISBN: 978-90of contemporary Austrian literature and Exile Studies, including Erste Briefe/First Letters aus dem Exil 1945-1950. (Un)mögliche Gespräche. Fallbeispiele des literarischen und künstlerischen Exil, co-edited with Primus Heinz Kucher and Johannes Evelein.

For more information see brill.com

Order information: Order online at brill.com +44330 333 0049 | customerservices@brill.com Submission information: brill.com/authors

Titles published by Brill | Fink, Brill | mentis or Brill | Schöningh: +49(o)71 5413279216 | brill@brocom.de 